\title{
Modified technique for preparation of venous circulation resin casts in the cirrhotic liver
}

\section{Técnica modificada para preparo do molde de resina da circulação venosa no fígado cirrótico}

José Olímpio Maia de Vasconcelos Filho, tCBC-PE; laécio leitão Batista²; Guilherme Benjamin Brandão Pitta3; Claudio Moura LACERDA, TCBC-PE ${ }^{3}$

\begin{abstract}
A B S T R A C T
This study describes two major adaptations for the preparation of resin casts in human cirrhotic liver, harvested at the time of transplantation. The first is the way of fixing the catheter in the ostia of the hepatic and portal veins through a cerclage, so as to prevent displacement of the catheter and / or leakage of the resin during its injection. The second is the extension of corrosion time in the NaOH solution, averaging 6.8 days, with daily replacement the solution until complete removal of parenchymal tissue. We applied the method in 14 cirrhotic livers, with good filling and coloring of the portal and hepatic vein territories, using different colors. This allows an anatomical study of these vessels, able to complement the knowledge of the histopathology in research work, and the planning of therapeutic procedures, such as the TransJugular Intrahepatic Port-Systemic Shunt (TIPS).
\end{abstract}

Keywords: Liver circulation. Fibrosis. Corrosion casting. Liver cirrhosis.

\section{INTRODUCTION}

$\mathrm{R}^{\mathrm{s}}$ esin casts have been an important means of anatomical studies $^{1-4}$. Uflacker et $a^{5}$ published a preparation technique for vascular casts in normal liver, in which they used cadaver livers, without disease, so that the hepatic vessels were preserved, which greatly facilitated the introduction of catheters and injection of the acrylic resin. Moreover, the lack of fibrosis in the organs studied allowed occurring complete corrosion of the liver parenchyma within 24 hours in 5\% $\mathrm{NaOH}$ solution.

We reviewed the literature by accessing the database of PubMed, Medline, SciELO and Lilacs, and selecting analytical and descriptive studies that evaluated the hepatic venous anatomy in cirrhotic by preparation with resin injection. We did not find similar studies reported in explanted cirrhotic livers, which display parenchymal hardening and in which vascular section is held next to the parenchyma, hindering the introduction of catheters.

The aim of this paper is to present a modified mold preparation technique in resin for explanted livers affected by cirrhosis.

\section{TECHNICAL NOTE}

We studied 14 livers explanted from patients (10 men and 4 women, with a mean age of 47.3 years - range 20 to 69) who underwent liver transplantation, after signing an Informed Consent Form. This study was approved by the Ethics in Research Committee of HUOC / PROCAPE Hospital Complex (UPE) and received the number 85,448. All explants had cirrhosis (alcoholic, C virus, or unknown cause). We did not harvest organs from patients with suspected malignancy (hepatocellular carcinoma or other) or hepatitis B cirrhosis. After removal of the organ and identification of hepatic veins and the portal vein ostia, we introduced a \# 12 polyethylene catheter in each branch of the porta and hepatic veins. We fixed the catheter in place through a cerclage of the ostium to prevent displacement of the catheter and / or leakage of the resin during injection (Figure 1A).

We opted for the dental acrylic resin Jet $®$ (Classico Dental Articles - Campo Limpo Paulista - SP) due to fast drying (with gelation after 3-4 minutes), without catalyst after placement of the polymerizer.

1 - Faculty of Medical Sciences (FCM), Pernambuco University (UPE), Recife, PE, Brazil. 2 - Oswaldo University Cruz Hospital, Pernambuco University (UPE), Recife, PE, Brazil. 3 - School of Medical Sciences, Alagoas State University of Health Sciences (UNCISAL), Maceio, AL, Brazil. 
In separate containers, we prepared the resin with red or blue dye in the ratio of one to one between the liquid phase and the polymerizer, injecting immediately after mixing, with to $20 \mathrm{ml}$ syringe. In the portal system we injected the red resin, and in the hepatic veins, the blue one.

After injection in all liver veins, the organ was kept in "rest" for a period of 60 minutes. Thereafter, we immersed it in a $7.5 \% \mathrm{NaOH}$ solution, for complete removal of the parenchyma. Every day, we washed the specimen in running water and replaced the solution with a new one until all the tissue was remove. (Figure 1B).

The organ corrosion time ranged from five to 12 days, with an average of 6.8 days, and venous vascular tree proved to be well filled until the venular territory in all cases. In 12 explants there were three hepatic veins,
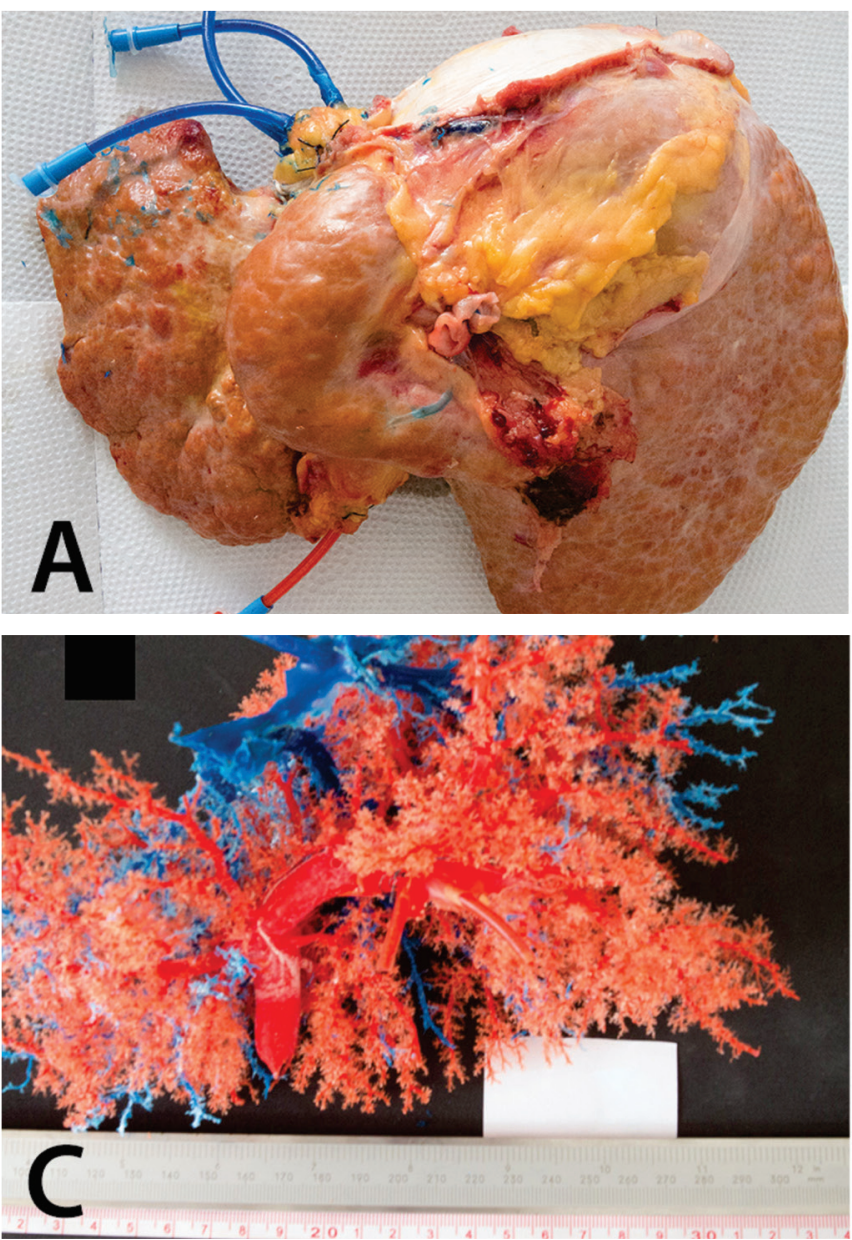

and in two, four hepatic veins. All accessory veins were related to the territory of the right hepatic vein. There was a partially rechanneled thrombosis in the right branch of the portal vein in one explant.

\section{DISCUSSION}

In 1994, Uflacker et al. ${ }^{5}$ studied the liver anatomy in 24 cadavers without liver disease using the injection of resin through the long stumps of the portal and hepatic veins, prepared for this purpose.

After an extensive literature review, we could not find studies on the venous circulation of the cirrhotic liver in humans with the resin injection technique. Taking into account that this work uses liver explants from patients undergoing liver transplantation, the greatest difficulty for preparation of resin casts was
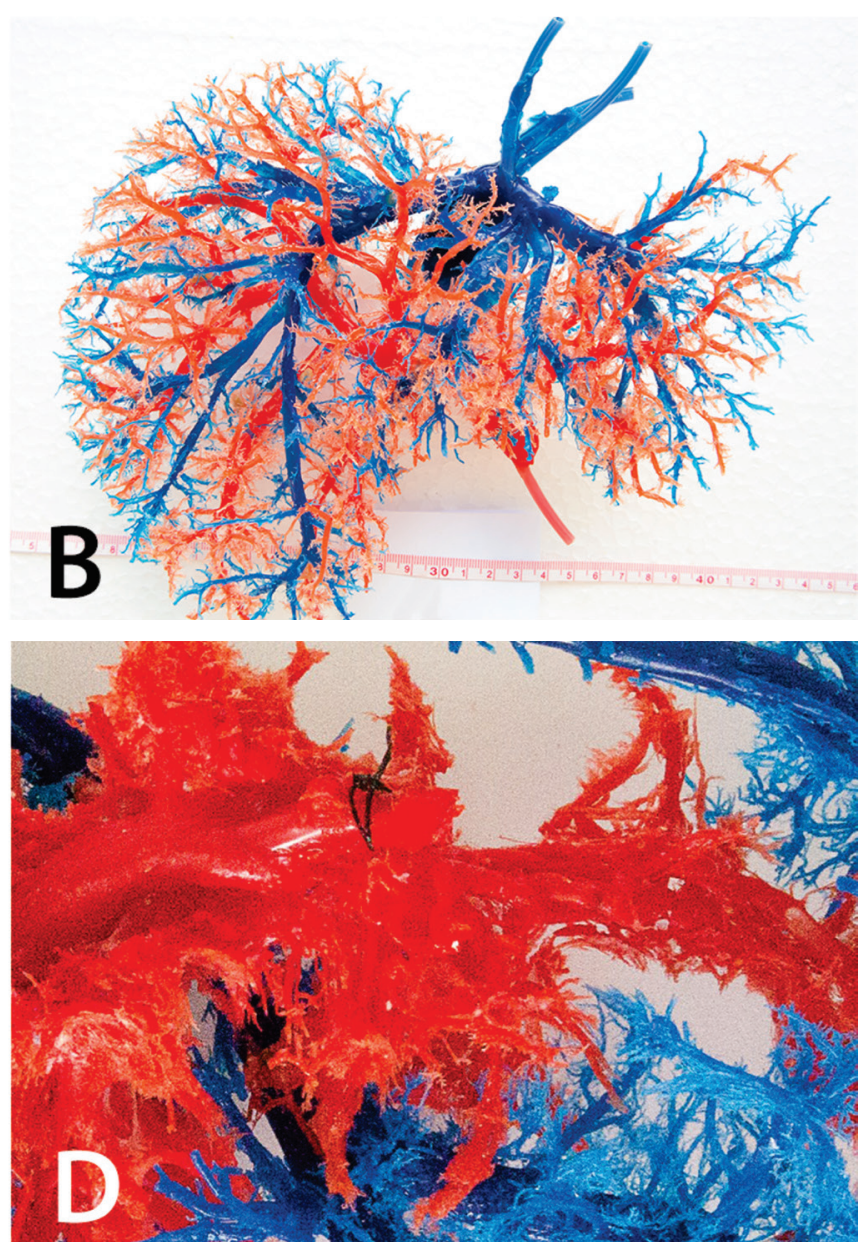

Figure 1. A) Posterior aspect of the liver, with catheters in the hepatic (blue) and portal (red) veins; B) Hepatic venous bed, after complete removal of the parenchyma. One can observe the catheters in the portal and hepatic veins; C) Important dissociation between the portal circulation and hepatic veins. In the lower field, there is a dilated umbilicus vein (collateral venous circulation); D) Disorganization of the microcirculation and signs of thrombosis (with recanalization) of the right portal branch (right). 
the catheterization of the venous bed, as venous section are made as close as possible to the explanted organ, aiming to leave a greater vascular stump for anastomosis with the graft.

In the absence of studies using cirrhotic liver explant and resin, we proposed ostial cerclage for fixation of the catheter, allowing good filling of the venous bed, preventing displacement of the catheter, the leakage of the resin, as well as the occluding of small branches that drain very close to catheterized ostia. Furthermore, we propose the use a mold daily washing with $\mathrm{NaOH}$ until complete disappearance of the parenchyma. The difference in corrosion time found in this work and in the literature, and between different organs in this work, was probably due to the different degrees of fibrotic liver disease, with variable hardening.
The moldings obtained in this study are adequate for venous anatomical studies of the liver, showing the vascular and anatomical variations, occlusion, with or without recanalization, and collateral vessels associated with portal hypertension (Figure $1 C$ and $\mathrm{D}$ ). The detailed description of the hepatic venous circulation parameters, such as size and length and, above all, the relationship between hepatic and portal veins, including the distance and the spatial relationship between the two (anterior, posterior, superior, inferior), may help greatly in the planning of minimally invasive percutaneous procedures, such as intrahepatic port-systemic shunt performed by transjugular access (TIPS), indicated for the treatment of upper gastrointestinal bleeding, unresponsive to medication and endoscopic therapy.

\section{R E S U M O}

Este estudo descreve duas importantes adaptações para o preparo de moldes de resina em fígado humano cirrótico, captado no momento do transplante: a primeira, é a maneira de fixação dos cateteres nos "óstios" das veias hepáticas e porta, através de uma "cerclagem" dos mesmos, de modo a evitar o deslocamento do cateter e/ou extravasamento da resina durante sua injeção, e a segunda, é o prolongamento do tempo de corrosão na solução de $\mathrm{NaOH}$, atingindo a média de 6,8 dias, com a substituição diária da solução, até a remoção completa do tecido parenquimatoso. O método foi empregado em 14 fígados cirróticos com bom preenchimento e coloração dos territórios das veias porta e hepáticas, utilizando cores distintas. Isto permite um estudo anatômico desses vasos, capaz de complementar os conhecimentos da histopatologia em trabalhos de pesquisa, e planejar procedimentos terapêuticos como a derivação porto-sistêmica intra-hepática transjugular (TIPS - Transjugular Intrahepatic Postosystemic Shunt).

Descritores: Circulação Hepática. Fibrose. Molde Por Corrosão. Cirrose Hepática.

\section{REFERENCES}

1. Debbaut C, Segers P, Cornillie P, Casteleyn C, Dierick $\mathrm{M}$, Laleman $\mathrm{W}$, et al. Analyzing the human liver vascular architecture by combining vascular corrosion casting and micro-CT scanning: a feasibility study. J Anat. 2014;224(4):509-17. Epub 2014 Jan 17.

2. De Sordi N, Bombardi C, Chiocchetti R, Clavenzani $P$, Trerè $C$, Canova $M$, et al. A new method of producing casts for anatomical studies. Anat Sci Int. 2014;89(4):255-65. Epub 2014 May 1.

3. Oliveira IM, Mindêllo MMA, Martins YO, Silva Filho AR. Análise de peças anatômicas preservadas com resina de poliéster para estudo em anatomia humana. Rev Col Bras Cir. [Internet] 2013 Feb [cited 2015 Sep 13]; 40(1):76-80. Available from: http://www.scielo.br/scielo.php?script=sci_arttex-
t\&pid=S0100-69912013000100014\&lng=en

4. Suwa F, Uemura M, Takemura A, Toda I, Fang YR, $X U$ YJ, et al. Acrylic resin injection method for blood vessel investigations. Okajimas Folia Anat Jpn. 2013;90(2):23-9.

5. Uflacker R, Reichert P, D'Albuquerque LC, de Oliveira e Silva A. Liver anatomy applied to the placement of transjugular intrahepatic portosystemic shunts. Radiology.1994;191(3):705-12.

Received in: 17/06/2016

Accepted for publication: 21/07/2016

Conflict of interest: none.

Source of funding: none.

\section{Mailing address:}

José Olimpio de Vasconcelos Maia Filho

E-mail: jolimpiomaia@gmail.com 